Огляди

DOI: 10.31793/1680-1466.2020.25-2.143

\title{
Механізми дії метформіну за діабету та пов'язаних із діабетом патологій
}

\section{Л.К. Соколова, В.М. Пушкарьов, О.І. Ковзун}

ДУ «Інститут ендокринології та обміну речовин ім. В.П. Комісаренка НАМН України»

\begin{abstract}
Резюме. Метформін (МФ) — основний пероральний препарат, який використовується в клініці для лікування пацієнтів із цукровим діабетом 2-го типу (ЦД2) понад 60 років. Предіабет - метаболічний стан, що характе-

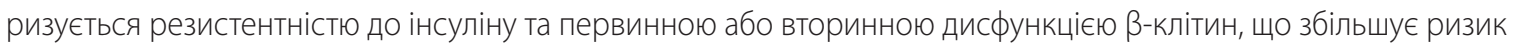
ЦД2. Отримані дані підтверджують роль МФ у запобіганні ЦД2 в людей із предіабетом. Його ефективність для затримки або запобігання виникненню діабету доведено у великих, добре обгрунтованих і спланованих рандомізованих дослідженнях. За діабету МФ знижує гіперглікемію, пригнічуючи глюконеогенез у печінці через активацію шляху LKB/AMPK, а також підвищує чутливість до інсуліну - ефект, що підсилює опосередковану інсуліном супресію продукції глюкози в печінці й утилізацію глюкози в скелетних м'язах. Дію МФ пов'язано з руйнуванням мітохондріального комплексу I і зменшенням продукції АТР, посиленням автофагії та іншими механізмами. Отримані дані надійно свідчать про зв'язок ЦД із порушеннями когнітивних здібностей людини. За діабету відбуваються структурні та функціональні зміни в нервовій системі та її кровоносних судинах. ЦД прискорює розвиток хвороби Альцгеймера, стимулюючи утворення сенильних бляшок і нейрофібрилярних клубочків. Хворі на діабет, які приймають МФ, меншою мірою схильні до когнітивних розладів. МФ запобігає апоптозу в первинних нейронах, ефективно посилює споживання глюкози в інсулінорезистентних клітинах. Нейропротекторні ефекти МФ, мабуть, пов'язано з його цукрознижуючими, антиоксидантними й антиапоптотичними властивостями. Відомо, що хворі на ЦД характеризуються підвищеним ризиком канцерогенезу, а в разі захворювання на рак їхня здатність до виживання $\in$ нижчою, ніж у недіабетичних пацієнтів. Антидіабетична терапія гальмує клітинний ріст, проліферацію та метаболізм і, як наслідок, впливає на потенціал онкогенезу. Гіперінсулінемія та гіперглікемія $\epsilon$ добре встановленими чинниками ризику канцерогенезу, тому зниження їх рівня є важливим моментом у запобіганні злоякісній трансформації клітин. МФ має протипухлинні властивості та може пригнічувати онкогенез за допомогою системних і клітинних механізмів. Цей препарат справляє пряму, спрямовану на ракові клітини, та непряму дію, впливаючи на системну інсулінемію та глікемію.
\end{abstract}

Ключові слова: метформін, предіабет, діабет, ожиріння, когнітивна дисфункція, канцерогенез.

Метформін (МФ), гідрохлорид 1,1-диметилбігуанід - основний пероральний препарат, який використовується в клініці для

\footnotetext{
* Адреса для листування (Correspondence): ДУ «Інститут ендокринології та обміну речовин ім. В.П. Комісаренка НАМН України», вул. Вишгородська, 69, м. Київ, 04114 Україна. E-mail: pushkarev.vm@gmail.com

соЛ.К. Соколова, В.М. Пушкарьов, О.І. Ковзун
}

лікування пацієнтів із цукровим діабетом 2-го типу (ЦД2) понад 60 років, і показано, що він безпечний навіть за тривалого застосування. Завдяки його ефективності та доступній ціні МФ приймають понад 150 мільйонів людей щорічно. МФ знижує гіперглікемію за рахунок 
Огляди

пригнічення глюконеогенезу в печінці поряд із посиленням трансдукції сигналів інсуліну (Ins). Проте механізм його дії залишається недостатньо вивченим, надто щодо участі тонких сигнальних механізмів в ефектах МФ [1].

\section{Предіабет}

Предіабет - це метаболічний стан, що характеризується резистентністю до інсуліну (IP) і первинною або вторинною дисфункцією $\beta$-клітин, що збільшує ризик ЦД2 [2]. Американська діабетична асоціація визначає предіабет як порушення толерантності до глюкози (IGT) або порушення рівня глюкози в крові натще (IFG), або і те, й інше [3]. Вважається, що високо-нормальний рівень НbA1c також є переддіабетичним станом [4]. Чинники ризику предіабету включають: родинний діабет, надмірну масу тіла (надто абдомінальне ожиріння), вік понад 45 років, гестаційний діабет, надмірну масу тіла в дітей, гіпертонію та фізичну бездіяльність, належність до певних етнічних груп. Рівень глюкози понад норму, але нижчий від діагностичного порогу діабету, пов'язано з підвищеним ризиком розвитку серцево-судинних захворювань (СС3) і смерті [2]. Отже, гальмування прогресії від IGT до ЦД2 є важливою стратегією підтримки здоров'я.

Рандомізовані дослідження показали, що МФ є найефективнішим пероральним гіпоглікемічним засобом для зниження частоти СС і смертності в пацієнтів із ЦД і вважається препаратом першої лінії. У результаті метааналізу ефектів МФ в осіб із ризиком ЦД дійшли висновку, що лікування МФ приводить до значного гальмування розвитку ЦД2 [2].

Поширеність як ЦД2, так і предіабету останніми роками швидко зростає. Висока поширеність предіабету підживлює розвиток глобальної пандемії діабету, отже оптимізація лікування діабету є світовим клінічним пріоритетом. Люди з комбінацією IFG та IGT мають підвищений ризик розвитку діабету порівняно з особами, які мають лише один із цих станів. Навіть помірне, але тривале підвищення рівня глюкози в плазмі крові, яке відповідає IFG або IGT, пов'язано 3 пошкодженням судинної системи. Предіабетична дисглікемія також збільшує ризик виникнення несприятливих серцево-судинних подій (таких, як інфаркт міокарда, інсульт або серцево-судинна смерть). Крім того, як і IP, предіабет часто співіснує з іншими серцево-судинними чинниками ризику, пов'язаними з метаболічним синдромом, такими як підвищення артеріального тиску та дисліпідемія. Резистентність до інсуліну, яка виявляється рано в патогенезі дисглікемії i, ймовірно, присутня в більшості осіб із предіабетом, сама по собі є важливим прогностичним показником підвищеного ризику розвитку діабету або ССЗ. Гальмування прогресуючої резистентності до інсуліну та дисфункції $\beta$-клітин, пов’язаних із дисглікемією, є ключовим чинником запобігання або затримки перетворення предіабету на клінічний ЦД2 [4, 5].

МФ діє, насамперед, посилюючи дію інсуліну в печінці та зменшуючи швидкість продукції глюкози. Поліпшення дії інсуліну в скелетних м'язах також сприяє терапевтичній дії МФ, призводячи до посилення утилізації глюкози. Разом ці ефекти знижують рівень глюкози в крові в умовах гіперглікемії, водночас не індукуючи гіпоглікемію. MФ XR нормалізував IFG приблизно у двох п'ятих осіб із діабетом. Посилення анаеробного метаболізму в стінці кишечника також, ймовірно, є клінічно значущим антигіперглікемічним механізмом дії МФ [4, 5]. Показано також, що МФ підвищуе рівень циркуляції глюкагоноподібного пептиду 1 (GLP-1) за рахунок збільшення секреції самого GLP-1 та/або зменшення активності дипептидилпептидази-4 (DPP4), ферменту, що головним чином відповідає за інактивацію GLP-1 у тканинах і кровообігу. МФ може також індукувати апрегуляцію експресії рецепторів GLP-1 на поверхні $\beta$-клітин підшлункової залози. Оскільки GLP-1 посилює глюкозозалежне вивільнення інсуліну 3 підшлункової залози, цей механізм може забезпечити помірну підтримку функції $\beta$-клітини. Також постулюється вплив МФ на мікробіом кишечника [6]. Лікування МФ нормалізує метаболізм глікогену та пригнічує як синтез глікогену, так і фосфорилювання, що може сприяти його профілактичному впливу на виникнення ЦД2 [7].

Механізм дії метформіну, напевно, пов'язаний із пригніченням мітохондріального дихання на рівні комплексу I дихального ланцюга. Внаслідок зсуву клітинного енергетичного балансу зростає активність АМР-кінази, яка 
сприяє дії інсуліну та знижує глюконеогенез у печінці. Збільшення рівня цАМФ у циркуляції також протидіє гіперглікемічній дії глюкагону. МФ потрапляє в клітини за допомогою транспортера органічних катіонів 1 (ОСТ1), і поліморфізм цього транспортера впливає на ефективність дії МФ у пацієнтів із ЦД2 [5].

МФ був першим протидіабетичним препаратом, який поліпшував серцево-судинний прогноз. Спостерігалося клінічно вірогідне зниження ризику виникнення цілої низки несприятливих наслідків стандартного лікування, що грунтувалося на дієті, включаючи загальну смертність, спричинену діабетом смертність і смертність від інфаркту міокарда, яке було більшим, ніж очікували, внаслідок поліпшення контролю рівня глюкози в крові. Тривале лікування МФ знижувало рівень циркулюючих маркерів ендотеліальної дисфункції, що відповідало захисному впливу на судинну систему, оскільки ендотеліальна дисфункція є початковою стадією атеросклерозу [8]. Запропоновано численні механізми, що пояснюють захисну дію МФ щодо судинної системи, включаючи поліпшений гемостаз (знижений потенціал атеротромботичної хвороби), гальмування запальних процесів в ендотелії судин, пригнічення окислювального стресу та утворення кінцевих продуктів глікування, поліпшення мікроциркуляції та модифікація клітинних процесів, що відбуваються під час атерогенезу [5].

Результати американської програми профілактики діабету (U.S. Diabetes Prevention Program) свідчать, що як зміни способу життя (що включає збільшення фізичних навантажень і втрату ваги), так і антигіперглікемічний препарат МФ затримують перехід від предіабету до ЦД2 [9, 10].

Загальну концентрацію проінсуліну, а також співвідношення проінсулін/інсулін і проінсулін/С-пептид підвищено в дорослих із предіабетом. Крім того, гіперпроінсулінемію пов'язано з розвитком і тяжкістю перебігу ЦД2, і вона може слугувати зв’язком між порушеним контролем глікемії та ССЗ. Концентрація проінсуліну, що циркулює, знижується після змін способу життя або лікування МФ [9]. Проінсулін натще значно знижувався лише після тренувань із фізичними вправами в поєднанні з метформіном. Зниження після застосування лише МФ було близьким до такого після комбінованої терапії. Крім того, показники кліренсу інсуліну в стаціонарному стані під час гіперінсулінемічного еуглікемічного клемп-тесту також були значно вищими після 12 тижнів лікування МФ із фізичними вправами або без них. Відсутність зв'язку між змінами кліренсу проінсуліну й інсуліну та змінами чутливості до інсуліну та кількості інсуліну натще дозволяє припустити, що МФ і фізичні вправи різним чином впливають на взаємозв’язок між потребою в інсуліні (тканинна чутливість) і його постачанням (продукцією та секрецією). Єдиною групою, яка виявила статистично значне зниження проінсуліну, була група МФ + фізичні вправи, яка також відзначалась вірогідним зниженням концентрації глюкози натще. На додаток до пригнічення печінкового глюконеогенезу МФ може також впливати на сигнальні шляхи $\beta$-клітин, і цілком можливо, що МФ справляе прямий вплив на утворення інсуліну в людини [11]. Хоча лише фізичні вправи та МФ значно знижували концентрацію проінсуліну, картина змін у группах, що лікувалися лише МФ говорить, що останній може діяти безпосередньо на $\beta$-клітини, знижуючи продукцію інсуліну. Ця гіпотеза підтверджується даними, отриманими на ізольованих $\beta$-клітинах підшлункової залози, в яких МФ змінював внутрішньоклітинний процесинг інсуліну за допомогою механізму, пов'язаного з АМРК [12]. Можливо також, що МФ безпосередньо впливає на кліренс інсуліну в печінці та нирках через регуляцію ключових ферментів і функцій, що беруть участь у деградації інсуліну, тоді як фізичні вправи справляють мінімальний вплив на процес деградації. Поточні дослідження свідчать, що МФ може змінювати продукцію та кліренс інсуліну без необхідності зміни чутливості до інсуліну. Якщо це підтвердиться, можливі важливі клінічні наслідки. Наприклад, одним із шляхів для поліпшення чутливості до інсуліну є зменшення гіперінсулінемії та створення умов для «відпочинку» підшлункової залози задля збереження функції $\beta$-клітин [10].

Недавні дослідження показали, що участь АМРК-незалежних шляхів може пояснити деякі корисні метаболічні ефекти МФ, а також небажані побічні ефекти. Такі шляхи включають 
Огляди

індукцію мітохондріального стресу, гальмування мітохондріальних шатлів, зміни мікробіоти кишечника, пригнічення сигналінгу глюкагону, активацію автофагії, послаблення запальних процесів, індукцію рецепторів інкретинів і зменшення стресу ендоплазматичного ретикулуму. Ці дослідження розширили наше розуміння механізмів дії антидіабетичних засобів, а також патогенезу самого діабету. Їх результати можуть допомогти виявити нові мішені та шляхи лікування діабету та метаболічного синдрому, а також можуть мати широке значення для інших захворювань, крім діабету [13].

Широка доказова база, отримана внаслідок клінічних випробувань, і попередній клінічний досвід підтверджують ефективність та безпеку МФ для профілактики ЦД2, а також окреслюють коло осіб, для яких МФ буде найбільш ефективним. Поточні дані підтверджують роль МФ в запобіганні діабету на додаток до змін способу життя в людей із предіабетом. Доведено, що зміни стилю життя, спрямовані на індукцію схуднення, фармакологічні методи лікування (метформін, тіазолідиндіони, акарбоза, базальний інсулін і препарати для схуднення) та баріатрична хірургія знижують ризик прогресування ЦД2 у предіабетичних пацієнтів. Проте пацієнтам важко підтримувати здоровий спосіб життя, і втрачена вага, як правило, з часом відновлюється. МФ посилює дію інсуліну в печінці та скелетних м'язах, а його ефективність для затримки або запобігання виникненню ЦД2 доведено у великих, добре обгрунтованих і спланованих рандомізованих дослідженнях, таких як Програма профілактики діабету (Diabetes Prevention Program) та інших [14, 15].

\section{Діабет 2-го типу}

Збільшення продукування глюкози печінкою є основною причиною гіперглікемії натще у хворих на ЦД2. Загальновідомо, що дію МФ в основному пов'язано з пригніченням утворення глюкози в печінці за допомогою активації шляху LKB/AMPK [16]. МФ не активує LKB1 або AMPK безпосередньо, оскільки препарат не впливає на фосфорилювання АМРК у безклітинній системі, та не впливає на ферментативну активність AMPK [17], але здатний посилити активність АМРК шляхом стимуляції фосфорилювання a-субодиниці по залишку Thr172. Оскільки
LKB1 є конститутивно активною кіназою, МФ впливає на формування функціонального гетеротримерного комплексу АМРК, посилюючи фосфорилювання $\alpha$-субодиниці. Отримані дані підтверджують зв’язування МФ із субодиницями АМРК, що приводить до прискорення збирання гетеротримерного комплексу AMPK, а також до алостеричних змін, які роблять його доступнішим для фосфорилювання кіназою LKB1 по залишку Thr172. Формування комплексу АMPK також перешкоджає дефосфорилюванню Thr172 $\alpha$-субодиниці фосфатазою PР2C [17].

Комплекс І дихального ланцюга мітохондрій (NADH-убіхінон-оксидоредуктаза) є першим вбудованим у мембрану супермолекулярним комплексом у ланцюзі перенесення електронів. Комплекс I також передає чотири протони 3 матриці в міжмембранний простір, генеруючи високий електронний градієнт, який є джерелом енергії для синтезу АТР. Показано, що дію МФ пов’язано з руйнуванням мітохондріального комплексу I і зменшенням продукції АТР. Припускається, що зміна співвідношення AMP/ATP або ADP/ATP після пригнічення мітохондріального комплексу, у першу чергу відповідає за ефект МФ, і що це відбувається через АМРК-незалежні механізми. Також показано, що МФ підвищує рівень АМР шляхом пригнічення АМР-деамінази [18]. Крім того, підвищений рівень АМР після лікування МФ призводить до пригнічення аденілатциклази та зниження кількості сАМР, що веде до пригнічення сигнального шляху сАМР/PKA i, далі, глюконеогенезу [19]. Глюконеогенез процес енергоємний, в якому для синтезу однієї молекули глюкози з лактату або пірувату необхідно 4 молекули АТР і 2 молекули GTP, зменшення кількості ATP у присутності МФ може знижувати рівень глюконеогенезу [18]. Є дані також, що МФ пригнічує синтез глюкози в печінці шляхом пригнічення ферментативної активності мітохондріальної гліцерин-3-фосфатдегідрогенази (mG3PDH), яка блокує транспорт NADH із цитоплазми в мітохондрії [11]. Гліцерофосфатний і малатаспартатний човниковий механізм дозволяє цитоплазматичній відновленій формі NADH, що генерується внаслідок гліколізу, перейти в мітохондрії для продукції АТР і регенерації цитоплазматичного $\mathrm{NAD}+$. Пригнічення 
мітохондріального шаттла призводить до зростання цитозольного та зниження мітохондріального редокс-стану, що може погіршувати перетворення лактату лактатдегідрогеназою на піруват, а це, у свою чергу, призводить до зниження глюконеогенезу і накопичення лактату. Останній ефект іноді спостерігається в тварин і людей, які отримували МФ, і може бути причиною молочнокислого ацидозу одного з побічних ефектів МФ. Глюконеогенез із гліцерину також може бути порушений, оскільки перетворення гліцерин-3-фосфату на дигідроксіацетонфосфат ферментом mG3PDH у мітохондріях пригнічується МФ. Можливо, це новий механізм дії МФ, який може пояснити його здатність пригнічувати глюконеогенез і виробляти лактат [1].

Хоча МФ знижує гіперглікемію головним чином за рахунок пригнічення глюконеогенезу в печінці, встановлено, що МФ також підвищує чутливість до Ins - ефект, що підсилює опосередковану Ins супресію продукції глюкози в печінці та утилізацію глюкози в скелетних м'язах [1].

МФ може викликати комплексну відповідь на стрес (ISR) шляхом індукції мітохондріального стресу. Так, МФ індукував експресію FGF21 через вісь PERK/eIF-2a/ATF4 y гепатоцитах, пов'язану 3 гальмуванням активності мітохондріального комплексу I. МФ-індуковані ISR і експресія FGF21 не залежать від АMPК. За гасіння мітохондріальних ROS послаблюється індукція FGF21, що підкреслює роль мітохондріального стресу або мітохондріальних ROS в індукції ростового чинника. Після терапії МФ протягом 6 місяців у пацієнтів із ЦД2 рівні FGF21 у сироватці збільшувалися, що свідчить про можливу участь чинника в поліпшенні метаболізму після введення хворим ліків [13].

Не виключено, що пригнічення МФ продукції глюкози в печінці відбувається частково через вісь кишечник-мозок-печінка. Гострий ефект МФ є АМРК-залежним і включає активацію в ентероцитах протеїнкіназою A GLP-1 [20]. За ожиріння та високожирової дієти (HFD) змінюється склад мікрофлори кишечника та суттєво збільшується концентрація LPS у крові. Крім того, навіть одноразове введення ліпідів гризунам або людині різко збільшує рівень LPS у сироватці. На мишачій моделі LPS навіть у низьких дозах викликають подібні до HFD гіперглікемію натще і стійкість печінки до Ins. Ці дані свідчать, що LPS кишечника є критичним етіологічним чинником для розвитку IP. Нещодавно показано, що МФ модулює склад мікрофлори кишечника в мишей із HFD і у хворих на діабет, а також знижує рівень LPS у сироватці. Крім того, МФ може активувати АМРК у слизовій оболонці кишечника [20]. Раніше було показано, що HFD збільшує проникність кишечника для LPS, i AMPK грає важливу роль у підтримці цілісності кишкового бар'єра [21]. Отже, МФопосередкована активація АМКР, імовірно, обмежує вихід LPS із кишечника.

Печінка є основним органом, відповідальним за кліренс LPS. У клітинах печінки LPS зв'язуються 3 мультирецепторним комплексом, що складається 3 CD14, TLR4 i MD2 у ліпідних рафтах гепатоцитів та ініціює активацію IRAK i, згодом, сигнального каскаду NF-кB. Активація NF-кB провокує IP, а інактивація цього шляху захищає від розвитку IP, як показано на мишах із нокаутованим (p50) NF-кB. Крім того, пригнічення шляху NF-кB поліпшувало чутливість до Ins на моделі $\mathrm{db} /$ $\mathrm{db}$ мишей [22]. Цікавим є той факт, що активація AMPK у присутності агоніста AICAR, як і МФ-опосередкована активація АМРК, пригнічує каскад NF-кB [23]. Отже, пригнічення шляху NF-кB через стимуляцію МФ активності АМРК приводить до поліпшення передачі сигналу Ins. LPS індукує експресію PTEN, а МФ може пригнічувати експресію цієї фосфатази в преадипоцитах 3Т3. Цей ефект МФ залежить від АМРК - PTEN є ï регулятором, і шлях AMPK/PTEN відіграє важливу роль у регуляції запальних процесів [24].

Інкретини - група гормонів шлунковокишкового тракту, які збільшують секрецію Ins після приймання їжі та включають GLP-1 і шлунковий інгібуючий пептид (PYY). Інкретини було введено в клінічну практику для поліпшення глікемічного контролю без збільшення маси тіла. Ця терапія також позитивно впливає на масу та функцію $\beta$-клітин [13]. Зокрема, використання інкретину з МФ стало популярною терапевтичною комбінацією. Дослідження взаємозв'язку між механізмами дії МФ та інкретину [25] грунтувалося на даних, що свідчать про зростання рівня GLP-1 
Огляди

у плазмі людей з ожирінням і хворих на ЦД2, які отримували МФ. Останній підвищуе в плазмі рівень GLP-1, але не PYY, який локалізується разом із GLP-1 у L-клітинах кишечника. Підвищені рівні GLP-1 після лікування МФ не було пов'язано з гальмуванням (DPP4), яка руйнує інкретини, або з індукцією експресії генів проглюкагонових пептидів. В основі механізму збільшення рівня GLP-1 у відповідь на МФ припускають участь мускаринових рецепторів ацетилхоліну. Показано також пряму дію МФ на експресію GLP-1 у лінії L-клітин, опосередковану сигнальним каскадом Wnt [26]. Показано, що МФ підсилює експресію рецептора GLP-1 в острівцевих клітинах, яка залежала від PPAR $\alpha$, але не від активації АМКР [25]. Ці результати є базисом для комбінованої терапії з використанням МФ та інкретинів або інгібіторів DPP4, які збільшують рівні інкретинів, адже індукція експресії рецептора GLP-1 метформіном може справляти синергетичний ефект 3 інкретинами, що вводяться.

МФ може посилювати автофагію, оскільки АМРК регулює цей процес шляхом прямого фосфорилювання ULK1 (UNC-51-like kinase) i Beclin 1, що беруть участь в ініціації автофагії [27]. Автофагія є процесом внутрішньоклітинного перегрупування мембран з утворенням автофагосом зі здвоєними мембранами, що містять цитоплазматичні компоненти та органели, який прискорюється за нестачі поживних речовин. Автофагія має велике значення для постачання клітини нутрієнтами за дефіциту енергії, а також для функціонування мітохондрій та ER. Оскільки мітохондрії та ER відіграють дуже важливу роль у фізіології $\beta$-клітин і чутливості до Ins, автофагія справляє істотний вплив на метаболізм організму в цілому. Посилення автофагії поліпшує профіль обміну речовин за метаболічного стресу [26, 28], що може бути пов'язано з ослабленням низькорівневого запалення тканини, викликаного ожирінням. Захист панкреатичних $\beta$-клітин від ліпоапоптозу в присутності МФ пов’язано з активацією автофагії [29]. МФ прискорює утилізацію в $\beta$-клітинах накопичених внаслідок автофагії вакуолей. Також МФ підсилює автофагію в серцевій тканині, сприяючи дисоціації комплексу Bcl-2 / Beclin 1 шляхом активації AMPK у тваринних моделях діабетичної кардіоміопатії [30]. Є дані також щодо послаблення жирової дистрофії печінки за допомогою МФ, шляхом активації автофагії через сигнальні шляхи SIRT1, a не AMPK [31]. Органели, які беруть участь в автофагії, включають не лише мітохондрії i ER, але й пероксисоми з лізосомами. Ліпідні краплі також можуть бути об'єктом автофагії (ліпофагія). Отже, прискорене видалення ліпідів шляхом ліпофагії може бути додатковим механізмом поліпшення обміну речовин i зменшення запалення тканин, пов'язаного 3 ожирінням [28].

Серед рецепторів вродженого імунітету NLRP3, член підродини NLRP, що входить у сімейство Nod-подібних рецепторів (NLR), відіграє вирішальну роль у запаленні тканин, пов'язаних із перевантаженням ліпідами й ожирінням. NLRP активує інфламасомний комплекс, який бере участь у дозріванні проIL-1 $\beta$ до IL-1 $\beta$. Потенційними ефекторами, які можуть активувати NLRP3 за метаболічних розладів, є ліпіди (FFA) і високий рівень глюкози. Показано, що МФ in vitro пригнічує продукцію IL-1 $\beta$ у макрофагах хворих ЦД2 шляхом активації АМРК. Лікування МФ хворих на ЦД2 протягом 2 місяців також збільшувало активність АМРК і знижувало процесинг IL-1 $\beta$ у макрофагах [32-34]. Хоча молекулярний механізм пригнічення інфламасом метформіном не з'ясовано, передбачається участь у ньому автофагії через активацію AMPK.

MФ також може впливати на ER-стрес, який відіграє важливу роль у розвитку IP і недостатності $\beta$-клітин за ЦД2. Механізм впливу ER-стресу на $\beta$-клітини остаточно не з’ясовано. Показано, що тіоредоксин-взаємодіючий білок (TXNIP), індукований ER-стресом і гіперактивацією IRE-1 $\alpha$ (inositol-requiring enzyme), $€$ найважливішим медіатором смерті $\beta$-клітин шляхом активації інфламасом. TXNIP є інгібітором та ендогенним партнером, що зв’язує тіоредоксин - повсюдно поширену оксидоредуктазу. Експресія TXNIP активується в острівцевих клітинах високою концентрацією глюкози, що призводить до активації NLRP3інфламасом після дисоціації з тіоредоксином у присутності ROS. Отже, активація NLRP3 може визначати як IP, так і загибель $\beta$-клітин. MФ знижує експресію TXNIP, ймовірно, шляхом активації АМРК, яка може пригнічувати 
рекрутування транскрипційних чинників, таких як комплекс ChREBP (carbohydrate response element-binding protein): Mlx (Maxlike protein X), до промотора TXNIP [35].

Попри доведені переваги МФ протипоказаний частині хворих ЦД2, в основному через побоювання з приводу зрідка виникаючих несприятливих наслідків лактатацидозу. Проте, незважаючи на думку, що підвищені концентрації МФ можуть привести до лактатацидозу, немає достатніх даних щодо того, який саме рівень накопичення препарату веде до гіперлактатемії. Фактично численні дослідження показують, що підвищений рівень циркулюючої молочної кислоти, що часто приписується МФ, може бути не пов'язаним із використанням препарату. По-перше, молочнокислий ацидоз виникає у пацієнтів із ЦД2 частіше, ніж у загальній популяції. Деякі дослідження показують, що підвищені рівні молочної кислоти спостерігаються як у пацієнтів, які приймають МФ, так і тих, кому приписані інші цукрознижувальні препарати [35]. По-друге, рівень МФ і рівень молочної кислоти не завжди корелюють, оскільки більші концентрації МФ не обов'язково пов'язано з тяжчим ступенем лактатацидозу. По-третє, рівень МФ не пов'язано зі смертністю хворих із лактатацидозом i, можливо, він лише відображає його першопричину (наприклад, гіпоксію, порушення гемодинаміки), яка є причиною сама по собі [36]. До того ж лактатацидоз може бути результатом широкого спектру різних умов, у тому числі сепсису, кардіогенного шоку, гіпокаліємії, тяжкої хвороби легенів і захворювань печінки [37].

Хоча МФ виводиться нирками, а його накопичення може призвести до лактатацидозу, наразі немає достатніх систематичних доказів на користь продовження практики відмови від МФ на підставі рівнів креатиніну. На сайті Адміністрації США з харчових продуктів і лікарських речовин (FDA) 2016 року з'явилася інформація про перегляд керівництва із застосування МФ, яке, як і щодо інших небрендових лікарських засобів, зазвичай залишається незмінним, незважаючи на нові дані та зміни в лікувальній практиці [38]. Сьогодні рекомендації FDA включають граничні показники швидкості клубочкової фільтрації (рСКФ), їх у цілому узгоджено з керівництвом
Національного інституту охорони здоров'я та якості медичної допомоги Великобританії та схвалено Канадською діабетичною асоціацією й Австралійською діабетичною спільнотою. Терапію МФ можна продовжувати (або розпочинати) за рСКФ <60 мл/хв на 1,73 м², але слід ретельно контролювати ниркову функцію (кожні 3-6 місяців). Дозу МФ слід переглянути та зменшити (наприклад, на $50 \%$ або до напівмаксимальної дози) у пацієнтів із рСКФ $<45$ мл/хв на 1,73 м², і ниркову функцію також слід ретельно контролювати (кожні 3 місяці). Проте починати приймання МФ пацієнтам із такими показниками не слід. Препарат слід відмінити, щойно рСКФ впаде до рівня

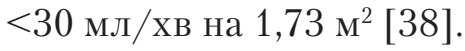

Тепер відомо, що лактатацидоз, викликаний недостатнім кліренсом МФ нирками, є досить рідкісною подією й трапляється в середньому в 0,03 випадку на 1000 пацієнтів на рік [39]. Парадокс ситуації полягає ще й в тому, що більшість хворих на ЦД2 не доживали б до лактатацидозу, не прймаючи МФ.

Отже, ризик побічних ефектів МФ є досить низьким порівняно з множинними перевагами його використання.

\section{Когнітивні порушення}

МФ - бігуанід, рекомендований для лікування ЦД2 і найбільш широко використовуваний сенсибілізатор інсуліну проти периферичної резистентності до гормону. Він знижує гіперглікемію та гіперінсулінемію за рахунок ослаблення IP. МФ в основному діє на печінку, знижуючи вихід глюкози. Вважається, що його ефект щодо сенсибілізації печінки та скелетних м'язів до інсуліну опосредковується АМРК [16, 40, 41].

Виявлено, що пацієнти із діабетом, які приймають МФ, меншою мірою виявляють когнітивну дисфункцію [42]. Ці результати узгоджуються 3 іншими, які показали, що ефект МФ пов’язано з поліпшеною когніцією в пацієнтів із ЦД2 [43]. Дослідження серед пацієнтів віком 50 років і більше показало, що використання МФ значно знижує ризик розвитку деменції [40]. Також є дані, що використання МФ асоціюється 3 ліпшою когнітивною функцією в пацієнтів із хворобою Хантінгтона [44].

Відомо, що МФ має нейропротекторні властивості, запобігаючи апоптозу в первинних нейронах. Він ефективно посилює 
Огляди

утилізацію глюкози в інсулінорезистентних нейронах [45], а також нормалізує проліферацію та диференціювання нейробластів у субгранулярній зоні зубчастої звивини гіпокампа в діабетичних щурів [46]. Дослідження киндлінгу, викликаного пентилентетразолом, показало, що МФ пригнічує прогресування порушення, поліпшує когнітивні процеси та послаблює окислювальний стрес мозку [47]. Також на хронічній L-метіоніновій моделі ослаблення пам'яті він запобігав когнітивним порушенням, ймовірно, шляхом зниження окисного стресу в гіпокампі [48]. Показано, що МФ запобігає погіршенню просторової референтної пам'яті, пов'язаної з HFD, у щурів [49] - знижувалися рівень транскрипції нейротропного чинника мозку, чинника росту нервів, нейротрофіну-3 та експресія найважливішого чинника антиоксидантного механізму - Nrf2. У дослідженні, проведеному на мишах $\mathrm{db} / \mathrm{db}$ - моделі спонтанного діабету 3 гіперінсулінемією, оцінювали ефекти МФ на когнітивні функції та виявили, що лікування протягом 6 тижнів значно поліпшувало пам'ять, включаючи відновлення тривалої потенціації (LTP - long-term potentiation) і нормалізацію деяких змін мозку на молекулярному рівні - зокрема, МФ знижував експресію RAGE й активність NF-кB [41].

Застосування МФ протягом року поліпшувало пам'ять у літніх (середній вік 65 років) огрядних людей, які мали амнестичні помірні когнітивні розлади. Також показано, що довгострокове лікування МФ може знизити ризик когнітивного спаду [43]. Ефекти МФ раніше пов'язували 3 його здатністю запобігати мітохондріальній дисфункції в тканинах мозку, відновлюючи навчальну поведінку [50]. У пацієнтів із ЦД2 МФ, мабуть, впливає на метаболізм у білій речовині та сайтах, пов'язаних із семантичною пам'яттю [51]. 3 іншого боку, дослідження показали, що тривале використання МФ дещо збільшує ризик розвитку хвороби Альцгеймера в пацієнтів. Такий ефект МФ на когнітивні характеристики може бути викликаний залежним від нього дефіцитом вітаміну $\mathrm{B}_{12}$, що вважається основною причиною зниження пізнавальних здібностей [52]. Показано, що в пацієнтів, які приймають МФ, знижується абсорбція вітаміну $\mathrm{B}_{12}$. Відомо, що поглинання комплексного чинника $\mathrm{B}_{12}$ рецепторами клітин клубової кишки залежить від наявності кальцію. МФ впливає на дію кальцію на клітинну мембрану, і додавання кальцію per os поліпшує абсорбцію вітаміну $\mathrm{B}_{12}$, порушену МФ. Ці дані свідчать, що вітамін $\mathrm{B}_{12}$ у поєднанні 3 кальцієм можуть усунути викликаний МФ дефіцит вітаміну $\mathrm{B}_{12}$ і поліпшити когнітивні результати [53]. В іншій праці показано, що введення МФ самцям мишей будь-якого віку не впливало на рівень глюкози в крові, масу тіла та редокс-гомеостаз. Також не виявлено позитивного впливу на вікові спади психомоторних, когнітивних або сенсорних функцій. Водночас лікування МФ негативно впливало на просторову пам'ять і гостроту зору, а також зменшувало активність супероксидисмутази в тканинах мозку.

Отже, лікування МФ може бути пов'язано зі шкідливими ефектами на ЦНС [54]. Проте в більшості досліджень виявлено позитивні ефекти МФ, який захищає мережу периферичних судин за рахунок зменшення запалення, викликаного активацією NF-кB, а також ослаблення ендотеліальної дисфункції та захисту периферичного ендотелію через активацію АМРК [55, 56]. Натомість між периферичними судинами та кровоносними судинами мозку існує багато відмінностей [57], тому екстраполювати ці дані слід з обережністю. У діабетичних тварин, які отримували МФ, поліпшувалася просторова пам'ять. У гіпокампі таких тварин перед лікуванням спостерігали реактивний гліоз, втрату нейронів, активацію сигналінгу NF-кB, високі рівні IL-1 i VEGF. Крім того, у цих тварин були низькими оцінки Т-лабіринт-тесту. Лікування МФ пригнічувало експресію маркерів астроцитів і мікроглії - GFAP, IBA-1 (ionized calciumbinding adapter-1) і знижувало рівні маркерів запалення (р-IкB, IL-1 i VEGF), підвищуючи рівні p-AMPK, eNOS і збільшуючи (судячи 3 маркерів Fox-1 i NeuN) виживання нейронів, що знаходило відображення в показниках просторової пам'яті діабетичних тварин [57]. Активація АМРК справляє терапевтичний ефект через пригнічення нейрозапалення в ЦНС [58], блокування в первинних астроцитах і мікроглії IFN- $\gamma$-залежної експресії генів, включаючи CCL2, TNF- $\alpha$, CXCL10 та індуцибельної синтази оксиду азоту (iNOS), модулювання STAT1 [59]. 
$\mathrm{y}$ гіпокампі $\mathrm{db} / \mathrm{db}$ мишей виявлено підвищений вміст білка тау, а також тау фосфорильованого по Ser396 та активованої с-jun $\mathrm{N}$-кінцевої кінази (JNK) порівняно з показниками недіабетичних контрольних $\mathrm{db}+$ мишей. МФ зменшував кількість тау, фосфо-тау й активованої JNK. У мишей $\mathrm{db} / \mathrm{db}$ було також підвищено рівні $А \beta$. У гіпокампі діабетичних мишей МФ гальмував зниження кількості синаптичного білка синаптофізину. Отже, МФ послаблює AD-подібні біохімічні зміни в мозку цих мишей [60].

Лікування мишей C57BL/6J цисплатином призводило до когнітивного дефіциту. Одночасне введення МФ запобігало когнітивним порушенням, викликаним цисплатином. На структурному рівні цисплатин зменшував когерентність волокон білої речовини в корі головного мозку. Крім того, після лікування цисплатином зменшувалася кількість дендритних шипів і гальмувалася нейрональна арборизація (розгалуження). Введення МФ запобігало всім цим структурним порушенням у мишей, які отримували цисплатин. Також показано, що спільне введення МФ захищає від індукованої цисплатином периферичної нейропатії [61]. МФ долає гематоенцефалічний бар’єр і здійснює нейропротекторну дію в моделях ішемічного інсульту, а також щодо викликаного запаленням пошкодження головного мозку. Є дані, що МФ сприяє диференціюванню мікроглії до супресорного фенотипу M2, який сприяє загоєнню ран, що може визначати позитивний вплив МФ на пошкоджені тканини головного мозку [62].

Виявлено, що МФ помітно пригнічує експресію й активність $\beta$-секретази 1 (BACE1) у культивованих клітинах та in vivo, тим самим зменшуючи кількість продуктів розщеплення BACE1 i, зокрема, А $\beta$. Крім того, є свідчення, що МФ знижує активність ацетилхолінестерази, відповідальної за деградацію ацетилхоліну нейротрансмітера, що бере участь у процесах навчання та пам'яті [63]. Відзначено слабкий вплив МФ на бутирилхолінестеразу, яка бере участь в утворенні сенильних бляшок [64].

МФ не лише знижує рівень глюкози в плазмі, а й характеризується сприятливим впливом на ліпідний профіль сироватки, послаблює адгезію запальних клітин до ендотелію, посилює автофагію та проявляє протизапальні, антиапоптотичні й антиоксидантні властивості [65]. Так, показано, що МФ знижує індуковану IL-1 $\beta$ активацію NF-кB, прозапальних кіназ Akt, p38MAPK, ERK, а також секрецію запальних цитокінів IL-6 і IL-8 [63].

Відомо, що хронічне введення великих доз L-метіоніну призводить до гіпергомоцистеїнемії та подальшого розвитку цереброваскулярних захворювань, включаючи інсульт, атеросклероз і судинну деменцію [66]. Крім того, гіпергомоцистеїнемію пов’язано з підвищеними рівнями окисного стресу та перекисного окислення ліпідів, які негативно впливають на формування пам'яті [48]. Гіпергомоцистеїнемія також провокує дисфункцію ендотеліальних клітин, яка порушує кровопостачання мозку та призводить до подальшого когнітивного спаду. Дослідження показали, що МФ має антиоксидантну активність, необхідну для відновлення когнітивної функції. Хронічне введення L-метіоніну призводило до погіршення як короткострокової, так і тривалої пам'яті, тоді як лікування МФ запобігало цьому ефекту. Крім того, L-метіонін викликав значне підвищення кількості окисленого глютатіону, тіобарбітуратів, поряд зі зменшенням співвідношення глютатіон / окислений глютатіон, активності каталази та глютатіонпероксидази. Всі ці процеси нормалізуються обробкою МФ. Отже, лікування МФ запобігає погіршенню пам'яті, викликаному L-метіоніном, ймовірно, шляхом нормалізації окисного стресу в гіпокампі [48].

Отримані дані надійно свідчать про зв'язок Цд із порушеннями когнітивних здібностей людини. За діабету відбуваються структурні та функціональні зміни в нервовій системі та їі кровоносних судинах. ЦД прискорює розвиток хвороби Альцгеймера, стимулюючи утворення сенильних бляшок і нейрофібрилярних клубочків. Ключовими чинниками даного ускладнення діабету є гіпер- і гіпоглікемія, а також порушення передачі сигналів інсуліну/IGF. Хворі на ЦД2, які приймають МФ, меншою мірою схильні до когнітивних розладів. Нейропротекторні ефекти МФ, мабуть, пов'язано з його цукрознижувальними, антиоксидантними й антиапоптотичними властивостями.

Кореляція між антидіабетичною терапією та ризиком онкогенезу

Вважається, що антидіабетична терапія гальмує клітинний ріст, проліферацію та 
Огляди

метаболізм i, як наслідок, впливає на потенціал онкогенезу. Гіперінсулінемія та гіперглікемія є добре встановленими чинниками ризику канцерогенезу, тому їх зниження $\epsilon$ важливим моментом у запобіганні злоякісній трансформації клітин. Антидіабетичні препарати по-різному впливають на ризик розвитку раку через різний вплив на концентрацію інсуліну. Так, сульфанілсечовина й екзогенний інсулін підвищують рівень інсуліну, а МФ i тіазолідиндіони (TZD) здатні знижувати його концентрацію [67]. MФ i TZD також послаблюють резистентність до інсуліну. Ретроспективне когортне дослідження у Великобританії показало, що монотерапію МФ пов'язано з найменшим ризиком канцерогенезу. Препарати сульфанілсечовини підвищували ризик розвитку раку. В іншій праці показано, що антидіабетична терапія не впливає на ризик розвитку раку в пацієнтів із ЦД2 [68].

У цілому на тлі досить суперечливих ефектів цукрознижувальних препаратів найбільш вираженою протипухлинною дією характеризується МФ [16, 69].

Бігуанід МФ, сенсибілізатор інсуліну, рекомендований як препарат першої лінії для терапії ЦД2. Вважається, що МФ має протипухлинні властивості та може пригнічувати онкогенез за допомогою системних і клітинних механізмів. Цей препарат справляє пряму, спрямовану на ракові клітини, та непряму дію, впливаючи на системну інсулінемію та глікемію [70].

Дія метформіну на ракові стовбурові клітини (CSC)

Відомо, що невелика частина клітин у пухлинах людини є CSC, які забезпечують метастазування пухлин і стійкість до терапії. Спочатку повідомлялося про специфічну дію МФ проти стовбурових клітин РМЗ [71]. На ксенотрансплантатах миші показано, що поєднання МФ та доксорубіцину зменшує масу пухлини та запобігає рецидивам набагато ефективніше, ніж кожен із препаратів окремо. МФ може також синергічно взаємодіяти 3 трастузумабом - моноклональними антитілами до HER2, пригнічуючи самовідновлення та розподіл CSC і клітин-попередників у HER2позитивних карциномах [72]. МФ значно знижує виживання CSC, ï клоногенність, сфероутворюючу здатність (панкреатосфери) та посилює розпад панкреатосфер як у гемцитабін-чутливих, так і у гемцитабін-стійких клітинах раку підшлункової залози (РПЗ) [73].

Є також дані, що МФ впливає на стовбурові клітини раку яєчників, легень і простати, підвищуючи їх хемо- та радіочутливість [74]. Дію МФ на CSC можна пояснити таким чином. 1. Активація AMPK, яка веде до інактивації mTOR i пригнічення активності іiї ефекторів, що стоять нижче, таких як p70S6K1 (p70 ribosomal S6 kinase 1) і чинника ініціації трансляції еукаріот 4EBP1 (4E-binding protein 1). 2. Пригнічення індукованого TGF- $\beta$ епітеліально-мезенхімального переходу (EMT) шляхом збереження експресії Е-кадгерінів і запобігання експресії віментину. ЕМТ дозволяє стовбуровим клітинам покинути епітеліальний шар, перейти в кровоносну систему й утворити віддалені метастази [75]. 3. Індукція експресії мікроРНК-26а й інших специфічних мікроРНК [73]. 4. Пригнічення запальних шляхів, необхідних для трансформації та формування CSC [71]. Ці дослідження показують, що МФ може бути використаний для подолання терапевтичної резистентності багатьох видів раку.

\section{Системні ефекти метформіну на біохі- мію пухлини}

Основними системними, непрямими ефектами МФ є зниження рівня глюкози в сироватці за рахунок пригнічення глюконеогенезу та глікогенолізу в печінці, зниження абсорбції глюкози в шлунково-кишковому тракті та рівня циркулюючого інсуліну [70]. Гепатоцити сприйнятливі до дії МФ, оскільки вони експресують високий рівень білків ОСТ1 (octamer transcription factor), які переносять цей бігуанід у клітини печінки, та через високу концентрацію МФ у портальній циркуляції після перорального введення препарату. МФ індукує енергетичний стрес за рахунок зниження активності комплексу I у клітинах печінки та зниження глюконеогенезу LKB1/AMPKзалежними або незалежними механізмами [76]. Зниження печінкового глюконеогенезу приводить до зниження секреції глюкози, концентрації глюкози та рівня інсуліну в крові. Гіперінсулінемія, що супроводжується підвищеним рівнем С-пептиду, зазвичай спостерігається в пацієнтів із ЦД2 та обумовлює підвищений ризик онкогенезу, посиленого росту та високої агресивності ракових клітин. 
Дослідження in vivo показують, що МФ має сильнішу протипухлинну активність у мишей на високоенергетичній дієті. Отже, опосередковане МФ зниження гіперінсулінемії може призодити до пригнічення канцерогенезу в інсулін-респонсивних новоутвореннях [76]. Крім того, цей бігуанід стримує глюкагонзалежну секрецію глюкози 3 клітин печінки через накопичення AMP. Зниження ризику канцерогенезу товстої кишки, можливо, пояснюється високою локальною концентрацією препарату після перорального введення [76]. Крім того, МФ гальмує запальні процеси, пригнічуючи найважливіший прозапальний чинник NF-кB. Оскільки хронічне запалення та сам NF-кB провокують неопластичну трансформацію [77], МФ може потенційно відігравати суттєву роль у цьому процесі. Крім того, препарат індукує апоптоз шляхом пригнічення UPR (unfolded protein response) i, порушуючи метаболізм жирних кислот, стимулює продукування імунною системою CD8 Т-клітин [71].

Прямі, внутрішньоклітинні ефекти метформіну в пухлинних клітинах

Як уже зазначалося, пухлинні клітини характеризуються підвищеним рівнем гліколізу. Проте, навіть у гліколітичному середовищі спостерігається окисне фосфорилювання в мітохондріях, що приводить до синтезу АТФ [76]. МФ здатний інтерферувати з дихальним комплексом I (NADH-убіхінон-оксидоредуктаза), перериваючи мітохондріальне дихання, знижуючи продукцію АТФ i, відповідно, підвищуючи співвідношення АМФ/АТФ, що призводить до енергетичного стресу. Зниження рівня АТФ активує АМРК (ключовий датчик енергії та пухлинний супресор), що приводить до відновлення вмісту АТФ, підвищення клітинного поглинання глюкози та гліколізу [76]. Активована АМРК фосфорилює білок TSC2 (tuberous sclerosis complex protein 2) і пригнічyє mTORC1, що призводить до гальмування синтезу білка та росту клітин. Активація АМРК метформіном також індукує р53/p21-залежний апоптоз і пригнічення клітинного циклу за рахунок зниження експресії цикліну D1.

За певних умов МФ може пригнічувати mTORC1 через AMPK-незалежні механізми, пригнічуючи Rag GTРази або індукуючи експресію REDD1. МФ також може пригнічувати
mTOR незалежно від AMPK за рахунок зниження рівнів інсуліну й IGF-1. AMPK/mTORзалежне регулювання приводить до пригнічення синтезу білка, жирних кислот і чинників, які сприяють росту (інсулін, IGF-1, лептин, глюкоза) в ракових клітинах. Крім того, цей препарат активує LKB1 (liver kinase B1), яка є пухлинним супрессором [68]. Мутації LKB1 часто спостерігаються в пухлинах легенів або підшлункової залози, а також за синдрому Пейтца-Егерса, який призводить до різних типів раку. МФ може також впливати на мітохондріальне окисне фосфорилювання за рахунок зниження продукції ROS та утилізації $\mathrm{NADH}$ - чинника, що відіграє ключову роль у циклі трикарбонових кислот [76]. МФ також здатний пригнічувати сигналінг HIF-1 і секрецію VEGF, які мають вирішальне значення для виживання ракових клітин у гіпоксичному середовищі, патологічного ангіогенезу та метастазування. Припускають, що МФ інтерферує з мікроРНК і геном множинної лікарської стійкості 1 (MDR1), що кодує Р-глікопротеїн. Надекспресія останнього, яка зазвичай спостерігається в пухлинних клітинах, призводить до зниження ефективності хіміотерапії, посилюючи викид гідрофобних препаратів із клітини [76].

Взаємодія між апоптозом та автофагією, викликаною МФ, є ще одним чинником його протипухлинної активності. Показано, що МФ пригнічує розвиток меланоми та лімфоми шляхом індукції автофагії та, як наслідок, апоптозу. На клітини плоскоклітинної карциноми стравоходу МФ здійснює антинеопластичну дію in vitro та in vivo за допомогою інактиваціï Stat3 i репресії Bcl-2, посилюючи перехресні зв’язки між апоптозом та автофагією [78].

Можливості застосування метформіну для лікування раку

Комплексний мета-аналіз підтвердив, що МФ істотно знижує захворюваність на рак, у першу чергу - РПЗ, рак печінки та рак товстої кишки. Спостереження хворих на ЦД2, які приймали МФ, показало дозозалежне зниження захворюваності на рак у них. Серед користувачів МФ відносний ризик виникнення раку знижувався на 31\% порівняно з іншими антидіабетичними препаратами [68]. Як згадувалося, МФ поліпшує відповідь на звичайні 
Огляди

хіміотерапевтичні препарати, знищуючи CSC за багатьох типів раку. Епідеміологічні дані щодо протипухлинної активності МФ вказують на його потенціал як ад'юванта або неоад'ювантного хіміотерапевтичного засобу, або як підсилювача класичної хіміотерапії проти майже всіх видів раку.

3 іншого боку, рандомізоване клінічне дослідження показало, що додавання звичайної антидіабетичної дози МФ не поліпшувало стан пацієнтів із прогресуючим РПЗ і лікуванням гемцитабіном та ерлотинібом [79]. Очевидно, стандартні дози МФ не забезпечують достатньої концентрації, аби викликати енергетичний стрес. Встановлено зв’язок між терапією МФ і зниженим ризиком раку молочної залози (РM3) у трансгенних мишей HER-2/ neu [68]. Використовують також ефективну терапію РМЗ, що грунтується на комбінації МФ і доксорубіцину. Низькі дози МФ селективно руйнують стовбурові клітини РМЗ, стійкі до хіміотерапії. У результаті CSC знищувалися МФ, а ракові нестовбурові клітини вбивалися хіміотерапією [71]. Аналогічний позитивний ефект такої комбінованої терапії досягався з використанням МФ і трастузумабу (анти-HER2 моноклональних антитіл) або МФ і таксанів [68].

Отже, МФ знижував ризик РПЗ, раку печінки, простати, яєчників, легенів, нирок, голови та шиї та колоректального раку. Перспективними виявилися і комбінації МФ із протипухлинними препаратами, використовуваними для лікування цих пухлин.

\section{Висновки}

ЦД і рак є провідними причинами смерті в усьому світі. У зв’язку з тим, що ЦД2 може провокувати канцерогенез, важливо виключати чиннники ризику розвитку ЦД, що модифікуються, надто в пацієнтів із незмінними чинниками ризику (вік, стать, раса / етнічна приналежність, генетична схильність). Найважливішим змінним чинником як для ЦД2, так і для раку є ожиріння [80]. Зниження маси тіла зменшує IP, гіперінсулінемію та хронічне запалення, пов'язане з ожирінням. Численні дослідження показали, що ЦД підвищує ризик розвитку раку різних органів, за винятком раку передміхурової залози. Крім того факту, що хворі на ЦД характеризуються підвищеним ризиком канцерогенезу, у разі захворювання на рак їхня здатність до виживання є нижчою, ніж у недіабетичних пацієнтів. Згідно з отриманими даними, у хворих на ЦД зростає ризик захворювання на РПЗ, рак печінки, товстої та прямої кишки та сечового міхура. ЦД також підвищує ризик раку ендометрію та РМЗ, надто в жінок у постменопаузі. Результати досліджень, які оцінюють вплив ЦД на рак нирки та рак голови та шиї, є суперечливими [68].

У майбутніх дослідженнях слід звернути увагу на дозу МФ, а також можливість застосування інших бігуанідів, таких як фенформін, які мають фармакокінетичні переваги перед МФ.

Можлива протипухлинна активність антидіабетичних препаратів може зменшити ризик онкогенезу в пацієнтів із ЦД2, тому введення цих препаратів має велику цінність. У зв'язку 3 тим, що поширеність ЦД зростає, а підвищений ризик канцерогенезу у хворих на діабет підтверджується великою кількістю досліджень, діабетичним пацієнтам особливу увагу слід приділяти скринінгу на онкомаркери та профілактичним протипухлинним заходам.

В Україні зареєстровано оригінальний метформін Глюкофаж і метформін пролонгованої дії Глюкофаж XR (компанія Acino Group, Швейцарія). Саме Глюкофаж використовувався у великих клінічних дослідженнях, які продемонстрували здатність метформіну знижувати кардіоваскулярний ризик і смертність y пацієнтів із діабетом. Глюкофаж XR - це інноваційна форма метформіну з пролонгованим вивільненням, в основі якої лежить подвійний полімерний матрикс (патентована система дифузії через гелевий бар’єp GelShield ${ }^{\circledR}$ ). Препарат дозволяє ефективно контролювати глікемію протягом доби при прийомі 1 р/день і забезпечує кращу переносимість з боку шлунково-кишкового тракту порівняно зі звичайним метформіном.

Глюкофаж XR - єдиний метформін в Україні, дозволений для профілактики розвитку ЦД 2 типу в разі неефективності дієтотерапії й активної зміни способу життя.

Глюкофаж і Глюкофаж XR можуть призначатися як стартове лікування при ЦД 2 типу як у режимі монотерапії, так і в комбінації з іншими цукрознижувальними засобами. 


\section{Список використаної літератури}

1. An H, He L. Current understanding of metformin effect on the control of hyperglycemia in diabetes. J Endocrinol. 2016;228(3): R97-106.

2. Naidoo P, Wing J, Rambiritch V. Effect of sitagliptin and metformin on prediabetes progression to type 2 diabetes - a randomized, double-blind, double-arm, multicenter clinical trial: protocol for the sitagliptin and metformin in prediabetes (SiMePreD) study JMIR Res Protoc. 2016;5(3): e145.

3. American Diabetes Association Standards of medical care in diabetes - 2008. Diabetes Care. 2008;31(Suppl 1): S12-54.

4. Hostalek U, Gwilt M, Hildemann S. Therapeutic use of metformin in prediabetes and diabetes prevention drugs. 2015;75(10):1071-94.

5. Hostalek U, Zilahi Z. Observational study of the efficacy of prolonged-release metformin in people with prediabetes. Curr Med Res Opin. 2019:1-5

6. Wu T, Thazhath SS, Bound MJ, Jones KL, Horowitz M, et al. Mechanism of increase in plasma intact GLP-1 by metformin in type 2 diabetes: stimulation of GLP-1 secretion or reduction in plasma DPP-4 activity? Diabetes Res Clin Pract. 2014;106: e3-6.

7. Ailanen L, Bezborodkina NN, Virtanen L, Ruohonen ST, Malova AV et al. Metformin normalizes the structural changes in glycogen preceding prediabetes in mice overexpressing neuropeptide $\mathrm{Y}$ in noradrenergic neurons. Pharmacol Res Perspect. 2018;6(2): e00389.

8. Sardu C, Paolisso P, Sacra C, Mauro C, Minicucci F, et al. Effects of metformin therapy on coronary endothelial dysfunction in patients with prediabetes with stable angina and nonobstructive coronary artery stenosis: the CODYCE multicenter prospective study. Diabetes Care. 2019;42(10):1946-55.

9. Kitabchi AE, Temprosa M, Knowler WC, Kahn SE, Fowler SE, et al. Role of insulin secretion and sensitivity in the evolution of type 2 diabetes in the diabetes prevention program: effects of lifestyle intervention and metformin. Diabetes. 2005;54:2404-14.

10. Viskochil R, Malin SK, Blankenship JM, Braun B. Exercise training and metformin, but not exercise training alone, decreases insulin production and increases insulin clearance in adults with prediabetes. J Appl Physiol (1985). 2017; 123(1):243-8.

11. Madiraju AK, Erion DM, Rahimi Y, Zhang XM, Braddock DT, et al Metformin suppresses gluconeogenesis by inhibiting mitochondrial glycerophosphate dehydrogenase. Nature. 2014;510:542-6.

12. Masini M, Anello M, Bugliani M, Marselli L, Filipponi F, et al. Prevention by metformin of alterations induced by chronic exposure to high glucose in human islet beta cells is associated with preserved ATP/ADP ratio. Diabetes Res Clin Pract. 2014;104:163-70.

13. Hur KY, Lee MS. New mechanisms of metformin action: Focusing on mitochondria and the gut. J Diabetes Investig. 2015;6(6):600-9

14. Diabetes Prevention Program Research Group. Long-term safety, tolerability, and weight loss associated with metformin in the Diabetes Prevention Program Outcomes Study. Diabetes Care. 2012;35:731-7.

15. Moin T. should adults with prediabetes be prescribed metformin to prevent diabetes mellitus? Yes: high-quality evidence supports metformin use in persons at high risk. Am Fam Physician. 2019;100(3):134-5.

16. Тронько НД, Пушкарев ВМ, Соколова ЛК, Пушкарев ВВ, Ковзун ЕИ Молекулярные механизмы патогенеза сахарного диабета и его осложнений. К.: Издательский дом Медкнига, 2018 264 c. (Tronko ND, Pushkarev VM, Sokolova LK, Pushkarev VV, Kovzun EI Molecular mechanisms of the pathogenesis of diabetes mellitus and its complications. K .: Medknig Publishing House, 2018. 264 p.)

17. Meng S, Cao J, He Q, Xiong L, Chang E, et al. Metformin activates AMP-activated protein kinase by promoting formation of the abg heterotrimeric complex. J Biol Chem. 2015;290:3793-802.

18. Ouyang JY, Parakhia RA, Ochs RS. Metformin activates AMP kinase through inhibition of AMP deaminase. J Biol Chem. 2011;286:1-11.

19. Miller RA, Chu OW, Xie JX, Foretz M, Viollet B, et al. Biguanides suppress hepatic glucagon signalling by decreasing production of cyclic AMP. Nature. 2013;494:256-60.

20. Duca FA, Cote CD, Rasmussen BA, Zadeh-Tahmasebi M, Rutter GA, et al. Metformin activates a duodenal AMPK-dependent pathway to lower hepatic glucose production in rats. Nat Med. 2015;21:506-11.
21. Elamin EE, Masclee AA, Dekker J, Pieters HJ, Jonkers DM. Short-chain fatty acids activate AMP-activated protein kinase and ameliorate ethanol-induced intestinal barrier dysfunction in Caco-2 cell monolayers. J Nutr. 2013;143:1872-81.

22. Gao ZG, Yin J, Zhang J, He Q, McGuinness OP, et al. Inactivation of NF-k B p50 leads to insulin sensitization in liver through posttranslational inhibition of p70S6K. J Biol Chem. 2009;284:18368-76.

23. Huang NL, Chiang SH, Hsueh CH, Liang YJ, Chen YJ, et al. Metformin inhibits TNF-a-induced I k B kinase phosphorylation, I k B-a degradation and IL-6 production in endothelial cells through PI3K-dependent AMPK phosphorylation. Int J Cardiol. 2009;134:169-75

24. Lee SK, Lee JO, Kim JH, Kim SJ, You GY, et al. Metformin sensitizes insulin signaling through AMPK-mediated PTEN down-regulation in preadipocyte 3T3-L1 cells. J Cell Biochem. 2011;112:1259-67.

25. Maida A, Lamont BJ, Drucker DJ. Metformin regulates the incretin receptor axis via a pathway dependent on perixome proliferatoractivated receptor-a in mice. Diabetologia. 2011;54:339-49.

26. Kim MH, Jee JH, Park S, Lee MS, Kim KW, et al. Metformin enhances glucagon-like peptide 1 via cooperation between insulin and Wnt signaling. J Endocrinol. 2014;220:117-28.

27. Kim J, Kim YC, Fang C, Russell RC, Kim JH, et al. Differential regulation of distinct Vps34 complex by AMPK in nutrient stress and autophagy. Cell. 2013;152:290-303.

28. Lim YM, Lim H, Hur KY, Quan W, Lee HY, et al. Systemic autophagy insufficiency compromises adaptation to metabolic stress and facilitates progression from obesity to diabetes. Nat Commun. 2014;5:4934.

29. Jiang Y, Huang W, Wang J, Xu Z, He J, et al. Metformin plays a dual role in MIN6 pancreatic b cell function through AMPK-dependent autophagy. Int J Biochem Cell Biol. 2014;10:268-77.

30. He C, Zhu H, Li H, Zou MH, Xie Z. Dissociation of Bcl-2-Beclin1 complex by activated AMPK enhances cardiac autophagy and protects against cardiomyocyte apoptosis in diabetes. Diabetes. 2013;62:1270-81

31. Song YM, Lee YH, Kim JW, Ham DS, Kang ES, et al. Metformin alleviates hepatosteatosis by restoring SIRT1-mediated autophagy induction via an AMP-activated protein kinase-independent pathway. Autophagy. 2015;11(1):46-59.

32. Lee HM, Kim JJ, Kim HJ, Shong M, Ku BJ, et al. Upregulated NLRP3 inflammasome activation in patients with type 2 diabetes. Diabetes. 2013;62:194-204.

33. Соколова ЛК, Пушкарев ВМ, Бельчина ЮБ, Пушкарев ВВ, Тронько НД. Активность аденозинмонофосфат-активированной протеинкиназы в лимфоцитах при действии сахароснижающих препаратов. Доп НАН України. 2017;6:96-100. (Sokolova LC, Pushkarev VM, Belchin YuB, Pushkarev VV, Tronko ND. The activity of adenosine monophosphate-activated protein kinase in lymphocytes under the action of sugar-lowering drugs. Additional NAS of Ukraine. 2017; 6: 96-100).

34. Pushkarev V.V., Sokolova L.K., Pushkarev V.M., Belchina Y.B., Vatseba T.S., Tronko M.D. Effect of combined treatment with insulin and other hypoglycemic drugs on 5'AMP-activated protein kinase activity in lymphocytes in patients with diabetes mellitus. Проблеми ендокринної патології. 2019, № 3, С. 74-82.

35. Chai TF, Hong SY, He H, Zheng L, Hagen T, et al. A potential mechanism of metformin-mediated regulation of glucose homeostasis: inhibition of Thioredoxin-interacting protein (Txnip) gene expression. Cell Signal. 2012;24:1700-5.

36. Stades AM, Heikens JT, Erkelens DW, Holleman F, Hoekstra JB. Metformin and lactic acidosis: cause or coincidence? A review of case reports. J Intern Med. 2004;255:179-87.

37. Пушкарев ВМ, Соколова ЛК, Пушкарев ВВ, Бельчина ЮБ, Тронько НД. Активность АМРК в лимфоцитах больных сахарным диабетом при действии сахароснижающих препаратов. Эффект метформина. Пробл Ендокр Патол. 2016;4:2935. (Pushkarev VM, Sokolova LK, Pushkarev VV, Belchina YuB, Tronko ND. The activity of AMPK in the lymphocytes of patients with diabetes mellitus under the action of sugar-lowering drugs. The effect of metformin. Probl Endocr Patol. 2016; 4: 29-35).

38. FDA Drug Safety Communication: FDA revises warnings regarding use of the diabetes medicine metformin in certain patients with reduced kidney function. FDA's website. 2016. 
Огляди

39. Novelle MG, Ali A, Dieguez C, Bernier M, de Cabo R. Metformin: A hopeful promise in aging research. Cold Spring Harb Perspect Med. 2016;6: a025932.

40. Alagiakrishnan K, Sankaralingam S, Ghosh M, Mereu L, Senior P. Antidiabetic drugs and their potential role in treating mild cognitive impairment and Alzheimer's disease. Discov Med. 2013;16(90):277-86.

41. Palleria C, Leporini C, Maida F, Succurro E, De Sarro G, et al. Potential effects of current drug therapies on cognitive impairment in patients with type 2 diabetes. Front Neuroendocrinol. 2016;42:76-92.

42. Liccini A, Malmstrom TK, Morley JE. Metformin use and cognitive dysfunction among patients with diabetes mellitus. J Am Med Dir Assoc. 2016;17(11):1063-5.

43. Ng TP, Feng L, Yap KB, Lee TS, Tan CH, et al. Long-term metformin usage and cognitive function among older adults with diabetes. J Alzheimers Dis. 2014;41:61e68.

44. Hervás D, Fornés-Ferrer V, Gómez-Escribano AP, Sequedo MD, Peiró C, et al. Metformin intake associates with better cognitive function in patients with Huntington's disease. PLoS One. 2017;12(6): e0179283.

45. Gupta A, Bisht B, Dey CS. Peripheral insulin-sensitizer drug metformin ameliorates neuronal insulin resistance and Alzheimer'slike changes. Neuropharmacology. 2011;60:910-20.

46. Hwang IK, Kim IY, Joo EJ, Shin JH, Choi JW, et al. Metformin normalizes type 2 diabetes-induced decrease in cell proliferation and neuroblast differentiation in the rat dentate gyrus. Neurochem Res. 2010;35:645-50.

47. Zhao RR, Xu XC, Xu F, Zhang WL, Zhang WL, et al. Metformin protects against seizures, learning and memory impairments and oxidative damage induced by pentylenetetrazole-induced kindling in mice. Biochem Biophys Res Commun. 2014;448:414-7.

48. Alzoubi KH, Khabour OF, Al-Azzam SI, Tashtoush MH, Mhaidat NM. Metformin eased cognitive impairment induced by chronic L -methionine administration: potential role of oxidative stress. Curr Neuropharmacol. 2014;12:186-92.

49. Allard JS, Perez EJ, Fukui K, Carpenter P, Ingram DK, et al. Prolonged metformin treatment leads to reduced transcription of Nrf2 and neurotrophic factors without cognitive impairment in older C57BL/6J mice. Behav Brain Res. 2016;301:1-9.

50. Pintana H, Apaijai N, Chattipakorn N, Chattipakorn SC. DPP-4 inhibitors improve cognition and brain mitochondrial function of insulin-resistant rats. J Endocrinol. 2013;218:1-11.

51. Huang YC, Hsu CC, Lin WC. Effects of metformin on the cerebral metabolic changes in type 2 diabetic patients. Sci World J. 2014;2014:694326.

52. Moore EM, Mander AG, Ames D, Kotowicz MA, Carne RP, et al. Increased risk of cognitive impairment in patients with diabetes is associated with metformin. Diabetes Care. 2013;36:2981-7.

53. Luchsinger JA, Perez T, Chang H, Mehta P, Steffener J, et al. Metformin in amnestic mild cognitive impairment: results of a pilot randomized placebo controlled clinical trial. J Alzheimers Dis. 2016;51(2):501-14.

54. Thangthaeng N, Rutledge M, Wong JM, Vann PH, Forster MJ, et al. Metformin impairs spatial memory and visual acuity in old male mice. Aging Dis. 2017;8(1):17-30.

55. Correia S, Carvalho C, Santos MS, Seiça R, Oliveira CR, et al. Mechanisms of action of metformin in type 2 diabetes and associated complications: an overview. Mini-Reviews Med Chem. 2008;8:1343-54.

56. Sokolova LK, Pushkarev VM, Pushkarev VV, Kovzun OI, Tronko MD. Diabetes mellitus and cognitive dysfunction. The role of metformin in pathogenesis and treatment of cognitive dysfunction (literature review). Probl Endocrin Pathol. 2018;2:75-92.

57. Oliveira WH, Nunes AK, França ME, Santos LA, Lós DB, et al. Effects of metformin on inflammation and short-term memory in streptozotocin-induced diabetic mice. Brain Res. 2016;644:149-60.

58. Peixoto CA, Oliveira WH, Araújo SMDR, Nunes AKS. AMPK activation: Role in the signaling pathways of neuroinflammation and neurodegeneration. Exp Neurol. 2017;298(A):31-41.

59. Meares GP, Qin H, Liu Y, Holdbrooks AT, Benveniste EN. AMPactivated protein kinase restricts IFN- $\gamma$ signaling. J Immunol. 2013;190:372-80

60. Li J, Deng J, Sheng W, Zuo Z. Metformin attenuates Alzheimer's disease-like neuropathology in obese, leptin-resistant mice. Pharmacol Biochem Behav. 2012;101(4):564-74.
61. Zhou W, Kavelaars A, Heijnen CJ. Metformin prevents cisplatininduced cognitive impairment and brain damage in mice. PLoS One. 2016;11(3): e0151890.

62. Yang JC, Hirsh V, Schuler M, Yamamoto N, O'Byrne KJ, et al. Symptom control and quality of life in LUX-Lung 3: a phase III study of afatinib or cisplatin/pemetrexed in patients with advanced lung adenocarcinoma with EGFR mutations. J Clin Oncol. 2013;31:3342-50

63. Markowicz-Piasecka M, Sikora J, Szydłowska A, Skupień A, Mikiciuk-Olasik E, et al. Metformin - a future therapy for neurodegenerative diseases: theme: drug discovery, development and delivery in Alzheimer's disease. Guest editor: Davide Brambilla. Pharm Res. 2017;34(12):2614-27.

64. Darvesh S. Butyrylcholinesterase as a diagnostic and therapeutic target for Alzheimer's disease. Curr Alzheimer Res. 2016;13(10):1173-7.

65. Wang C, Liu C, Gao K, Zhao H, Zhou Z, et al. Metformin preconditioning provide neuroprotection through enhancement of autophagy and suppression of inflammation and apoptosis after spinal cord injury. Biochem Biophys Res Com. 2016;477:534-40.

66. Cacciapuoti F. Lowering homocysteine levels with folic acid and B-vitamins do not reduce early atherosclerosis, but could interfere with cognitive decline and Alzheimer's disease. J Thromb Thrombolysis. 2013;36(3):258-62.

67. Onitilo AA, Engel JM, Glurich I, Stankowski RV, Williams GM, et al. Diabetes and cancer II: role of diabetes medications and influence of shared risk factors. Cancer Causes Control. 2012;23:991-1008.

68. Wojciechowska J, Krajewski W, Bolanowski M, Kręcicki T, Zatoński T. Diabetes and cancer: a review of current knowledge. Exp Clin Endocrinol Diabetes. 2016;124(5):263-75.

69. Пушкарев ВМ, Соколова ЛК, Пушкарев ВВ, Тронько НД. Биохимические механизмы, связывающие диабет и рак Действие метформина. Ендокринологія. 2018;23(2):16779. (Pushkarev VM, Sokolova LK, Pushkarev VV, Tronko ND. Biochemical mechanisms linking diabetes and cancer. The action of metformin. Endocrinology. 2018; 23 (2): 167-79).

70. Rattan R, Ali Fehmi R, Munkarah A. Metformin: an emerging new therapeutic option for targeting cancer stem cells and metastasis. J Oncol. 2012;2012:928127.

71. Hirsch HA, Iliopoulos D, Struhl K. Metformin inhibits the inflammatory cancer stem cell growth. Proc Natl Acad Sci U S A. 2013;110:972-7.

72. Vazquez-Martin A, Oliveras-Ferraros C, Del Barco S, MartinCastillo B, Menendez JA. The antidiabetic drug metformin suppresses self-renewal and proliferation of trastuzumab-resistant tumor-initiating breast cancer stem cells. Breast Cancer Res Treat. 2011;126:355-64.

73. Bao B, Wang Z, Ali S, Ahmad A, Azmi AS, et al. Metformin inhibits cell proliferation, migration and invasion by attenuating CSC function mediated by deregulating miRNAs in pancreatic cancer cells. Cancer Prev Res (Phila). 2012;5(3):355-64.

74. Hua F, Yu JJ, Hu ZW. Diabetes and cancer, common threads and missing links. Cancer Lett. 2016;374(1):54-61.

75. Del Barco S, Vazquez-Martin A, Cufi S, Oliveras-Ferraros C, Bosch-Barrera J, et al. Metformin: multi-faceted protection against cancer. Oncotarget. 2011;2:896-917.

76. Pollak M. Potential applications for biguanides in oncology. J Clin Invest. 2013;123:3693-700.

77. Пушкарьов ВМ, Ковзун ОІ, Пушкарьов ВВ, Гуда ББ, Тронько МД. Хронічне запалення і рак. Значення ядерного фактоpa NF- kB. ЖАМHУ. 2015;21(3-4):287-98. (Pushkaryov VM, Kovzun OI, Pushkaryov VV, Guda BB, Tronko MD. Chronically inflamed and cancer. The value of the nuclear factor is NF-kB ZHAMNU. 2015; 21 (3-4): 287-98).

78. Feng $\mathrm{Y}, \mathrm{Ke} \mathrm{C}$, Tang Q, Dong H, Zheng X, et al. Metformin promotes autophagy and apoptosis in esophageal squamous cell carcinoma by downregulating Stat3 signaling. Cell Death Dis. 2014;5: e1088.

79. Kordes S, Pollak MN, Zwinderman AH, Mathôt RA, Weterman MJ, et al. Metformin in patients with advanced pancreatic cancer: a double-blind, randomised, placebo-controlled phase 2 trial. Lancet Oncol. 2015;16(7):839-47.

80. Klil-Drori AJ, Azoulay L, Pollak MN. Cancer, obesity, diabetes, and antidiabetic drugs: is the fog clearing? Nat Rev Clin Oncol. 2017;14(2):85-99. 


\section{Механизмы действия метформина при диабете и связанных с диабетом патологиях}

\section{Л.К. Соколова, В.М. Пушкарев, О.І. Ковзун}

ГУ «Институт эндокринологии и обмена веществ им. В.П. Комиссаренко НАМН Украины»

Резюме. Метформин (МФ) - основной пероральный препарат, который используется в клинике для лечения пациентов с сахарным диабетом 2-го типа (СД2) более 60 лет. Предиабет - метаболическое состояние, характеризующееся резистентностью к инсулину и первичной или вторичной дисфункцией $\beta$-клеток, что увеличивает риск СД2. Полученные данные подтверждают роль МФ в предупреждении СД2 у людей с предиабетом. Его эффективность для задержки или предупреждения возникновения ЦД2 доказана в крупных, хорошо обоснованных и спланированных рандомизированных исследованиях. При диабете МФ снижает гипергликемию, подавляя глюконеогенез в печени посредством активации пути LKB/AMPK, а также повышает чувствительность к инсулину - эффект, усиливающий опосредованную инсулином супрессию продукции глюкозы в печени и утилизацию глюкозы в скелетных мышцах. Действие МФ связано с разрушением митохондриального комплекса I и уменьшением продукции АТР, усилением аутофагии и другими механизмами. Полученные данные надежно свидетельствуют о связи СД с нарушениями когнитивных способностей человека. При диабете наблюдаются структурные и функциональные изменения в нервной системе и ее кровеносных сосудах. СД ускоряет развитие болезни Альцгеймера, стимулируя образование сенильных бляшек и нейрофибриллярных клубочков. Больные диабетом, принимающие МФ, в меньшей степени подвержены когнитивным расстройствам. МФ предотвращает апоптоз в первичных нейронах, эффективно усиливает потребление глюкозы в инсулинорезистентных клетках. Нейропротекторные эффекты МФ, вероятно, связаны с его сахароснижающими, антиоксидантными и антиапоптотическими свойствами Известно, что больные СД характеризуются повышенным риском канцерогенеза, а в случае заболевания раком их выживаемость ниже, чем у недиабетических пациентов. Противодиабетическая терапия тормозит клеточный рост, пролиферацию и метаболизм и, как следствие, влияет на потенциал онкогенеза. Гиперинсулинемия и гипергликемия являются хорошо установленными факторами риска канцерогенеза, поэтому снижение их уровня - важный момент в предотвращении злокачественной трансформации клеток. МФ обладает противоопухолевыми свойствами и может подавлять онкогенез с помощью системных и клеточных механизмов. Этот препарат оказывает прямое, направленное на раковые клетки, и косвенное воздействие, влияя на системную инсулинемию и гликемию.
Ключевые слова: метформин, предиабет, диабет, ожирение, когнитивная дисфункция, канцерогенез.

\section{The mechanisms of metformin action in diabetes and diabetes-related pathologies}

\section{L.K. Sokolova, V.M. Pushkarev, O.I. Kovzun}

SI «V.P. Komisarenko Institute of endocrinology and metabolism of NAMS of Ukraine»

Abstract. Metformin (MF) is the main oral drug used in the clinic to treat patients with type 2 diabetes mellitus (T2DM) for more than 60 years. Prediabetes is a metabolic condition characterized by insulin resistance and primary or secondary $\beta$-cell dysfunction, which increases the risk of T2DM. The findings confirm the role of MF in preventing diabetes in people with prediabetes. Its effectiveness in delaying or preventing the onset of diabetes has been proven in large, well-founded and well-planned randomized trials. In diabetes, MF reduces hyperglycemia by suppressing gluconeogenesis in the liver by activating the LKB/AMPK pathway, and also increases insulin sensitivity, an effect that enhances insulin-mediated suppression of glucose production in the liver and utilization of glucose in skeletal muscle. The action of MF is associated with the destruction of the mitochondrial complex I and a decrease in ATP production, increased autophagy and other mechanisms. The data obtained reliably indicate the relationship of diabetes with impaired human cognitive abilities. In diabetes, structural and functional changes are observed in the nervous system and its blood vessels. DM accelerates the development of Alzheimer's disease by stimulating the formation of senile plaques and neurofibrillary glomeruli. Diabetes patients taking MF are less susceptible to cognitive impairment. MF prevents apoptosis in primary neurons, effectively enhances glucose uptake in insulin-resistant cells. The neuroprotective effects of metformin are probably related to its hypoglycemic, antioxidant, and antiapoptotic properties. It is known that patients with diabetes are characterized by an increased risk of carcinogenesis, and in the case of cancer, their survival is lower than in non-diabetic patients. Antidiabetic therapy inhibits cell growth, proliferation and metabolism and, as a result, affects the potential of oncogenesis. Hyperinsulinemia and hyperglycemia are well-established risk factors for carcinogenesis, so reducing their level is an important point in preventing malignant transformation of cells. MF has antitumor properties and can suppress oncogenesis using systemic and cellular mechanisms. This drug has a direct, focused on cancer cells, and an indirect effect, affecting systemic insulinemia and glycemia in the blood.

Keywords: metformin, prediabetes, diabetes, obesity, cognitive dysfunction, carcinogenesis.

UA-GLUC-PUB-062020-039 